\title{
Anti-c-KIT Monoclonal Antibody CDX 0158
}

National Cancer Institute

\section{Source}

National Cancer Institute. Anti-c-KIT Monoclonal Antibody CDX0158. NCI Thesaurus.

Code C125620.

A humanized immunog lobulin (Ig) G1 monoclonal antibody against the stem cell factor receptor c-Kit (SCFR; KIT; CD117), with potential antineoplastic and anti-allergic activities. Upon administration, the anti-c-KIT monoclonal antibody CDX 0158 binds to and inhibits the activation of the cell surface antigen c-Kit. This leads to an inhibition of the activation of c-KIT-mediated signal transduction pathways and inhibits cell proliferation in cancer cells expressing c-Kit. In mast cells, inhibition of c-KIT and c-KIT-mediated signaling prevents mast cell activation, degranulation and subsequent cytokine release. c-Kit, a transmembrane protein and receptor tyrosine kinase, is overexpressed in various cell types, including certain cancer cells and mast cells; it plays a key role in the regulation of cell differentiation and proliferation. 